\title{
Evidence based medicine is the conscientious, explicit, and judicious use of current evidence in making decisions about the care of individual patients ${ }^{1}$
}

The 2nd. U.K. Workshop on Evidence Based Health Care, London, 11th-16th February 1996, with Dr. Trisha Greenhalgh (UCLMS) as co-ordinator, and Prof. David Sackett (Oxford), as orientator, constituted an important meeting to disseminate EBHC in UK and Europe. "Evidence Based Medicine is the conscientious, explicit, and judicious use of current best evidence in making decisions about the care of individuals patients" (Sackett, 1996). The methodology utilized was Problem-Based Learning (PBL), with small groups sessions with tutor and co-tutor as facilitators of the discussion process. The participants have been demonstrated that it's possible to teach EBHC using different strategies, approaches and resources. This Workshop was an excellent opportunity not only to share and receive informations about Clinical Epidemiology, Biostatistics and EBHC, but also to participate in a "learning to learn" active process to understand how to teach and learn EBHC.

$\mathrm{T}$ The "2nd United Kingdom Workshop on Evidence Based Health" Care was held at Whittington Hospital, London, addressing the theme "E.B.M. - Evidence-Based Medicine," using the methodological approach of Problem-Based Learning (P.B.L.), i.e., based on an active process of teaching and learning in small groups (on average eight students)relying on facilitators (a tutor and co-tutor).

The activities were developed under the auspices of the Department of Primary Attention, UCLMS-UniversityCollege London Medical School, headed by Professor Andy Haines. Dr. Trisha Greenhalgh coordinated the activities, which were under general direction of Professor

\section{Address for correspondence:}

Ricardo Shoiti Komatsu

Medicine College of Marilia

Av. Brig. Luís Antonio, 388 - cj. 35 - Bela Vista

São Paulo/SP - Brasil - CEP 01318-000
David Sackett, from the E.B.M. Working Group, Oxford University.

Besides the plenary sessions (two with Professor Sackett "On the Necessity of Evidence-Based Medicine" and "Focusing on Clinical Questions") we participated in meetings with librarians to establish research strategies for Medline, demonstrations of databases, (N.H.S. and Cochrane Center), and in activities of the group Public Health 1, as part of the Project U.N.I.-Marília (Kellogg Foundation), tutored by Dr. Kennedy Cruikshank, Senior Lecturer in Clinical Epidemiology at Manchester University, and Dr. Mary Walker, co-tutor, Research Administrator, CoDirector of the British Regional Heart Study; both with long experience in the small group dynamics.

The group was heterogeneous, critical (I believe there was a bias in the selection of candidates for the Workshop), and rich in experiences of teaching, research, and assistance. The group was formed by Prof. D.G. Cramp, clinical pathologist, of Health Management, Health Management Group, City University, London; Dr. Valerie 
Fischer, head of the Graduate Studies on Nursing, Hertfordshire University; Dr. Jennifer Worrol, rheumatologist at Whittington Hospital; Dr. Rumona Dickson, researcher at N.H.S. Centre for Reviews and Dissemination, York University; Dr. John Robson, associate professor in Epidemiology at Auckland University (New Zealand); Dr. Mary Pierce, senior lecturer in Public Health and Primary Attention, Hull University; and Dr. Meryl Deane, lecturer/consultant in Public Health and Primary Attention, Chelsea \& Westminster Hospital, London. Following the first "ice breaker" sessions, we formed a real team, concentrating on: "see one," "do one" and "teach one," and in "time in" and "time out."

It was a rich experience to share and receive information not only on Evidence Based Medicine, but also on how to teach, using the PBL methodology. It became evident that there are different presentations, formats, compositions, strategies and possibilities used in problembased learning for the transmission of information. These make the existence of active students and participants necessary for exchanging information, so that tutors and students have the opportunity to add to existing information.

It became clear that the approach for teaching Evidence Based Medicine in graduate courses must be associated with PBL methodology, which is currently being developed by us in a program for tutor education, advised by professors from MacMaster University. We intend to offer an Interactive Unit for Evidence Based Health Care, in PBL, as an elective course for fourth-year medical students, by the end of this year. This proposal was presented, analyzed with great receptiveness, and approved by the group at this Workshop.

The Marília Medical Faculty, stimulated by the institutionalization of UNI-Marília Project ("A New Initiative for Integration" of academy-health servicecommunity), has been engaged in the SPICE model for a proposal of a large-scale curricular revision: education centered on the Student, based on Problems, Integrated, orientated to the Community, and with Elective content.

Professor Sackett believes that this essential movement towards the rationalization of medical practice, conceived at McMaster University, Canada, will spread rapidly throughout the entire United Kingdom by the end of this century, and will constitute an important influence for the entire European Community.

To spearhead this movement in Brazil, we are counting on the Center for Research and Training in Clinical Epidemiology, Escola Paulista de Medicina, São Paulo Federal University, the Clinical Epidemiology Units of UFRJ, and in the near future, on the pasticipation of Ceara Federal University, Marília Medical Faculty, and the State University of Londrina.

As soon as possible, we hope to develop iniciatives similar to those of the United Kingdom here, since Evidence Based Medicine is a concrete step for the definite incorporation of clinical epidemiology knowledge, as well as for the critical evaluation of medical literature in our daily practice.

\section{RESUMO}

A 2a. Oficina de Trabalho sobre Cuidados de Saúde Baseados em Evidências (CSBE), londres, 11 a 26 de fevereiro de 1996 , com a Dra. Trisha Greenhalgh (UCLMS) como coordenadora, e o Prof. David Sackett (Oxford) como orientador, constituiu um importante encontro para disseminar os CSBE no Reino Unido e europa. "Medicina Baseada em Evidências é o consciencioso, explícito e judicioso uso da melhor e mais atual evidência na tomada de decisões sobre o cuidado com pacientes individuais"(Sackett, 1996). A metodologia utilizada foi a da Aprendizagem Baseada em Problemas, com sessões em pequenos grupos com tutor e co-tutor como facilitadores do processo de discussão. Os participantes demonstraram que é possivel ensinar CSBE usando diferentes estratégias, abordagens e recursos. Esta Oficina de Trabalho foi uma excelente oportunidade nāo somente para compartilhar e receber informações sobre Epidemiologia Clinica, Bioestatística e CSBE, mas para participar em ativo processo para entender como ensinar e aprender CSBE.

\section{REFERENCES}

1. Sackett DL, et al. Evidence based medicine: what it is and what it isn't. B M J 1996;312:71-2. 